Article

\title{
Evaluation of Environmental Naturalness: A Case Study in the Tietê-Jacaré Hydrographic Basin, São Paulo, Brazil
}

\author{
Diego Peruchi Trevisan ${ }^{1}$ (), Mayara Herrmann Ruggiero ${ }^{1}$, Polyanna da Conceição Bispo ${ }^{2, *}$ (D) Dayana Almeida ${ }^{1}$, \\ Maryam Imani ${ }^{3}\left(\mathbb{D}\right.$, Heiko Balzter ${ }^{4}\left(\mathbb{D}\right.$ and Luiz Eduardo Moschini ${ }^{1}(\mathbb{C}$ \\ 1 Environmental Sciences Department, Federal University of São Carlos, São Carlos 13565-905, Brazil; \\ diego.peruchi@gmail.com (D.P.T.); mayara.hruggiero@gmail.com (M.H.R.); almeida.dds@gmail.com (D.A.); \\ lemoschini@ufscar.br (L.E.M.) \\ 2 Department of Geography, School of Environment, Education and Development, University of Manchester, \\ Manchester M13 9PL, UK \\ 3 School of Engineering and the Built Environment, Bishop Hall Lane, Anglia Ruskin University, \\ Chelmsford CM1 1SQ, Essex, UK; maryam.imani@aru.ac.uk \\ 4 Centre for Landscape and Climate Research, National Centre for Earth Observation, University of Leicester, \\ Leicester LE1 7RH, UK; hb91@leicester.ac.uk \\ * Correspondence: polyanna.bispo@manchester.ac.uk; Tel.: +44-7783-320037
}

check for

updates

Citation: Trevisan, D.P.; Ruggiero, M.H.; Bispo, P.d.C.; Almeida, D.; Imani, M.; Balzter, H.; Moschini, L.E. Evaluation of Environmental Naturalness: A Case Study in the Tietê-Jacaré Hydrographic Basin, São Paulo, Brazil. Sustainability 2021, 13, 3021. https://doi.org/doi:10.3390/ su13063021

Academic Editor: Elena Cristina Rada

Received: 19 January 2021

Accepted: 3 March 2021

Published: 10 March 2021

Publisher's Note: MDPI stays neutral with regard to jurisdictional claims in published maps and institutional affiliations.

Copyright: (c) 2021 by the authors. Licensee MDPI, Basel, Switzerland. This article is an open access article distributed under the terms and conditions of the Creative Commons Attribution (CC BY) license (https:// creativecommons.org/licenses/by/ $4.0 /)$.

\begin{abstract}
The connection between humanity and nature has an organizational impact on land use/land, often changing landscapes' patterns. In this context, our study aims to analyze the changes in the landscape structure of the Tietê-Jacaré watershed, São Paulo state, Brazil, in 2007 and 2017, through the urbanity index. The landscape analysis described the temporal landscape patterns resulting from the influence of anthropogenic processes. This approach assumes that the environmental impacts are associated with the vulnerability of land use components. The urbanity index was utilized to analyze the landscape sustainability conditions in response to anthropogenic influence. We observed a reduction in vegetation areas (2.72\%), representing 32,149 ha, followed by an expansion of crops $(2.05 \%, 24,507.53 \mathrm{ha})$ and, as a result, a reduction of the landscape environmental quality with a growth of the areas with anthropic intervention. The development of anthropic activities, land use, and land cover changes could compromise the region's ecosystems negatively, e.g., through effects on soils that provide sustenance vegetation and afford energy for terrestrial life. The urbanity index expressed the conservation and natural state of the landscape studied. It is presented as an essential tool for diagnosing the environment and for the conservation of the ecosystem, allowing precise analysis of landscape elements and enabling accurate analysis of each fragment of the landscape.
\end{abstract}

Keywords: environmental indices; landscape planning; land use; land cover; watersheds

\section{Introduction}

The land cover reflects how much of a region is covered by forests, wetlands, impervious surfaces, agriculture, and other land and water types, and land use shows how people use the landscape for development, conservation, or mixed uses. Modifications in these places act as one of the main drivers of biodiversity loss, transforming ecosystem functions and services and, consequently, the landscape structure worldwide [1,2]. The changes in land use and land cover (LULC) caused mainly by anthropogenic activities are increasing over time in extent and intensity and are forecast to remain a significant driver influencing ecosystems now and in the future $[3,4]$. The most significant alterations in the landscapes related to landscape changes include urban and agricultural expansion, industrialization, and deforestation $[5,6]$.

The substitution of native forests for other land uses alters the landscape configuration, which assumes a fragmented mosaic character. When these occur without adequate 
planning to mitigate impacts, they can generate ecosystems with low resilience and resistance to natural or artificial disorders. With the development and growth of societies, the compatibility between natural resources and the preservation of ecosystems becomes necessary since the destruction of these resources changes the landscapes, reflecting on their ability to contribute with goods and services to society [2,4].

Research, programs, and public policies are needed to overcome these challenges and implement international environmental conventions such as the UN Agenda 2030 [7]. In this sense, the monitoring of the landscape structure and LULC changes is essential to understand its configuration and the drivers and impacts of anthropic activities on natural landscapes [8,9].

The landscape naturalness analysis, developed by O'Neil et al., (1988) [10], is one of the main methods used to exam landscapes for this purpose. The urbanity index studies the extension and insensitivity in which landscapes are modified by altered systems [11,12]. This index considers the proportion between areas with substantial anthropic interference, such as urban and agricultural areas, and natural and semi-natural biotopes, such as wetlands and vegetation.

The landscape monitoring analysis permits a study of the landscape characteristics and is an essential element for elaborating management strategies [13]. In the 20th century, with the increase of climate change, landscape and anthropic stress influences had become the subject of scientific and social debate. This discussion profoundly influences modern ecology development and, through trying to understand the LULC changes and their impacts on the natural process, produces an insight into ecosystem structures and functions $[14,15]$.

Numerous authors have developed indices of landscape spatial monitoring [6,10,16-21]. Such studies are related to different environmental, economic, and social contexts, which contribute to the comprehension of natural landscape changes through the interconnected analysis of different impacts and contexts that have negative and positive effects on the environment.

Geoprocessing techniques generate hypotheses surrounding landscape ecology and population issues [22]. This challenge aims to search for management concepts and methods that decrease ecosystems' negative impacts. In the last twenty years, there has been a search for qualitative and quantitative approaches to examine changes, determine spatial processes, and develop models. The development of landscape quantification methods has helped understand the associations between the landscape processes and partners [23,24].

An example can be found in the study conducted by Bellon et al., (2020) [25], which used a methodology to accomplish integrated landscape change analyses of interface areas using change detection methods. The authors found a vegetation loss inside protected areas and their legal buffer zones. The indicators also revealed LULC conversions from vegetation to farming, losses in productivity, the homogenization of natural forests, and an agricultural expansion.

In this context, the changes in Brazil's landscapes have increased in the last thirty years due to economic development and flexible environmental laws such as the Brazilian Forest Code (law $\left.n^{\circ} 12.651 / 2012\right)$, which changed conservation rules through protected spaces, reducing withdrawals close to water, for example. [26]. Urban and agricultural areas' expansion has amplified fragmentation, deforestation, and degradation processes in forests, resulting in a loss of biodiversity and negative impacts on climate change in the country's different biomes [27].

In this setting, the watersheds analysis, as the central unit of the landscape, is essential. These management units provide the integration of vital compartments, such as the water resources and the diversity of animal and vegetal species. In the Tietê-Jacaré watershed, where we developed this study, historical, ecological, and economic importance were observed, and a loss of vegetation and increased agricultural activities without environmental planning were identified $[22,28]$. 
It is necessary to develop research that seeks to understand anthropic activities' impacts and how they modify the landscape structure. These measures are used to compare landscapes, identify changes over time, and explore the effects of different configurations imposed by management practices [29,30].

The landscape naturalness is presented as an indicator utilized to analyzes the territorial organization of LULC and the quantity between natural areas and human interference. For example, urban and agricultural areas and natural biotopes, such as wetlands and vegetation, simulate the extent and intensity to which external systems dominate natural landscapes.

In this context, the geographical information system (GIS) was used as an efficient tool to characterize the landscape and the diagnostic analyses. GIS also allows the simulation of geographic space, natural processes, and spatial information integration [13,31]. The classification of landscape connectivity across large areas is made possible with approaches, such as circuit theory [32-34], that produce robust maps predicting multiple pathways and corridors across a landscape.

In this context, our study aims to analyze the changes in the landscape using the urbanity index in the Tiete-Jacaré watershed, São Paulo, Brazil, in 2007 and 2017, focusing on understanding the impacts of anthropic activities and how they have modified the landscape structure over time.

\section{Materials and Methods}

\subsection{Study Area}

The region integrates 37 municipalities with 1,500,000 inhabitants with a total area of 1,181,090 hectares (ha) and a drainage area of $8669.09 \mathrm{~km}$, which contains three main rivers: the Tietê River, the Jacaré-Guaçu River, and the Jacaré-Pepira River. Using the Köppen-Geiger classification, the climate of the region is between tropical humid (from October to March) and dry winter (from April to September), with a pluviometric average of $119.36 \mathrm{~mm}$ per month, totaling an average of $1432.32 \mathrm{~mm}$ per year $[33,34]$.

The region studied is inserted in two biodiversity hotspots: the Atlantic Forest (23\%) and the Brazilian Savanna (Cerrado) (77\%), regions that remain vital areas in the preservation and conservation of endemic fauna and flora, bounded by urban and agricultural activity, with the leading economy connected to the agroindustry and a predominance of sugar, alcohol, citrus, and cellulose activities. Other industry sectors, such as beverages, footwear, and metalworking, also stand out, concentrated in the largest municipalities such as Bauru, São Carlos, Araraquara, and Jaú [33,34].

The São Paulo state categorizes its water resources through the Water Resources Management Units (WRMU), instituted by State Laws n.7.663/1991 and 9.934/1994 [35,36]. There are twenty-two WRMUs in the state that were delimited by watershed or river basins theory. The regions are encompassed by water resources that converge to the main stream and that require a connection between research, governmental planning, society, and management [37]. The Tietê-Jacaré watershed is the Water Resources Management Units number 13 and is located in the state's central region, between the coordinates $49^{\circ} 14^{\prime}$ and $47^{\circ} 70^{\prime}$ West and $21^{\circ} 62^{\prime}$ and $22^{\circ} 79^{\prime}$ South (Figure 1 ).

Since the 18th century, the Tietê-Jacaré region has had an agricultural and industrial profile. Cattle and sugar production were the two main economic activities in São Paulo state. During the 19th century, coffee became the primary source of income for the country and the state, replacing sugarcane as the top Brazilian export for a certain period. The first decades of the 20th century were marked by an overproduction crisis, mainly due to the decrease in external demand resulting from the economic crisis of 1929. In response to the coffee export market crisis, there was an intensification of sugarcane production. Between 1931 and 1945, sugarcane had its production increased by $570 \%$, consolidating the state of São Paulo as the largest producer in Brazil, as it is today [33,34]. 


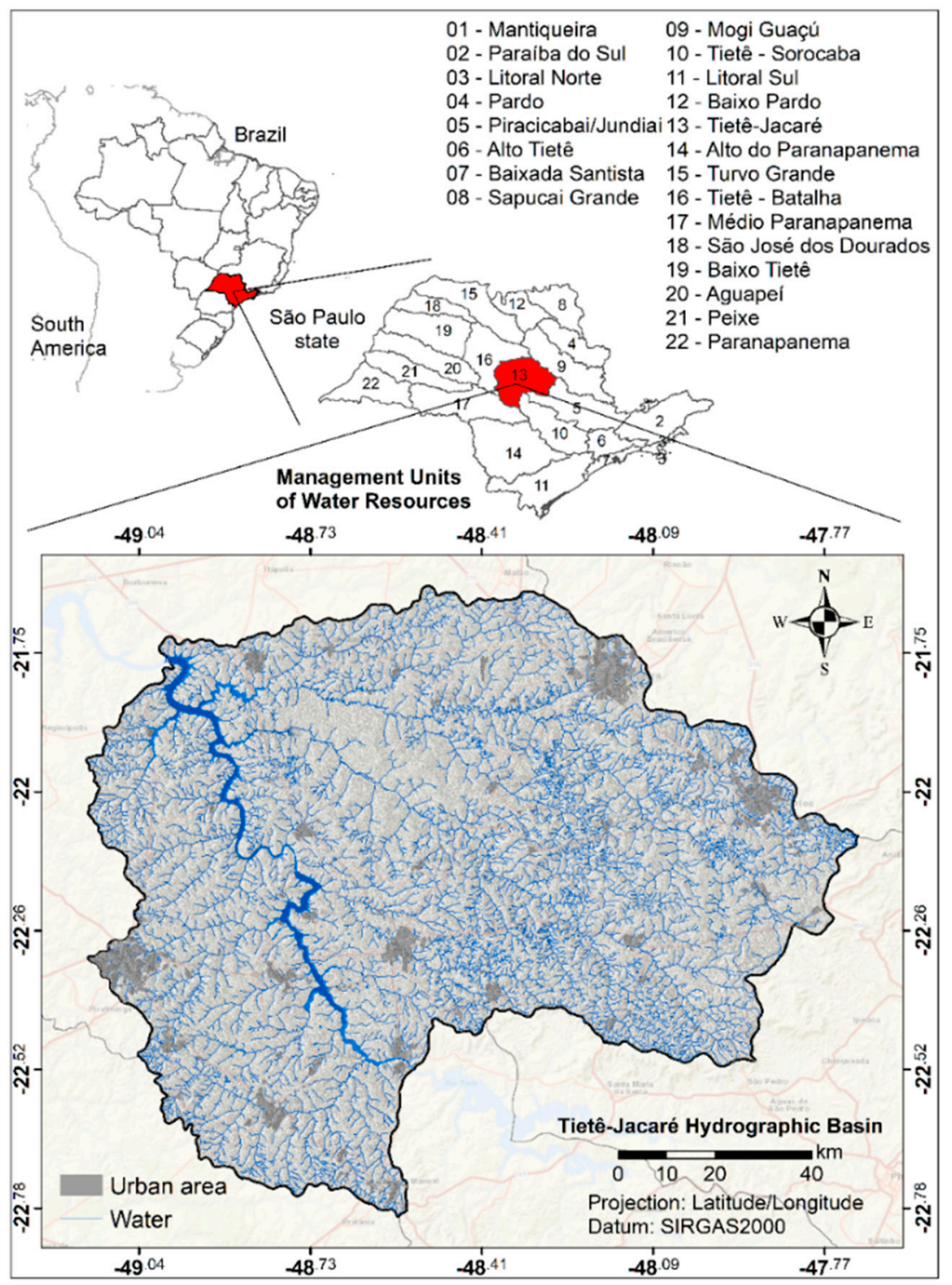

Figure 1. The geographic location of the Tietê-Jacaré watershed, São Paulo, Brazil.

Currently, the Tietê-Jacaré watershed presents a diversified economy, with emphasis on the sugar-alcohol complex, which extends throughout the region. Additionally, the planting and processing of citrus fruits occur mainly in São Carlos, Araraquara, and Jaú, representing a large part of the population. In the regions of Agudos, Araraquara, and Bauru, the beverage and paper sectors stand out; in Jaú is it the footwear industry; in São Carlos, fabrics and metal mechanics; in Ibitinga, embroidery; and Barra Bonita, Igaraçu do Tietê, and Brotas where the tourism industry is most prevalent [33,34].

Due to the development characteristics of this socio-economic and environmental context, which integrates municipalities with high urbanization, industrial, and agricultural potential inserted into essential natural ecosystem regions, the Tietê-Jacaré watershed has become an area with a high potential for monitoring and analyzing the impacts of changes in LULC and the interrelationship of anthropic development with natural ecosystems, focused on how these factors influence the conservation of the landscape.

\subsection{Methodology}

Our study involved four main steps. First, we collected data for the region's environmental characterization to contextualize the area and support further results and discussions. Second, we analyzed the LULC and used this analysis to apply the urban 
index in the third step. In the fourth and last step, we discussed the characteristics and results found in the region.

The geographic information system (GIS) was utilized to analyze and process the data (Figure 2), using the ArcGIS 10.8 with the geographical Universal Transverse Mercator projection (UTM), Zone 23 South, datum SIRGAS2000 for all information. The geographic data were downloaded from the Brazilian Institute of Geography and Statistics (IBGE), version 2018, and from the planialtimetric charts [38] in analog form on a 1:50.000 scale. The satellite images for the LULC data were provided from the Landsat 5 and 8 satellite [39] (Table 1). The study area's paths/rows were: 220/75, 220/76, 221/75 221/76, on the overpass dates of 30th April 2007, and 21st September 2017. For 2007, with the Landsat 5 sensor TM, bands 5/4/3 were used; for 2017, with the Landsat 8 sensor OLI/TIRS, bands $6 / 5 / 4$ were used.

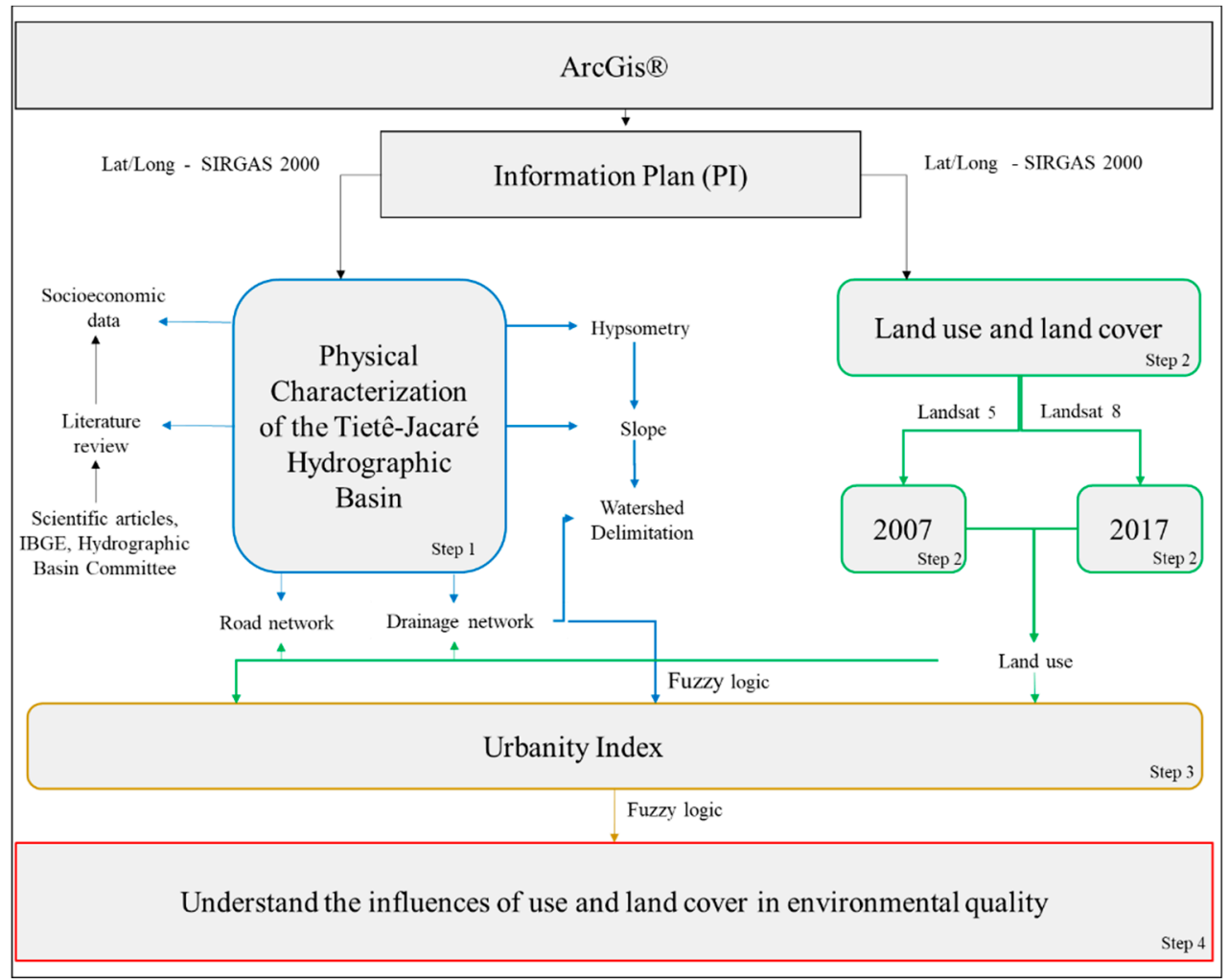

Figure 2. Work flowchart.

Table 1. Satellites and data images used in the study.

\begin{tabular}{cccccc}
\hline Satellite & Overpass & Path/Row & Bands & Pixel Resolution & Clouds (\%) \\
\hline Landsat 5 & 30th April 2007 & $220 / 75$ & $5 / 4 / 3$ & $30 \mathrm{~m}$ & 0 \\
Landsat 5 & 30th April 2007 & $220 / 76$ & $5 / 4 / 3$ & $30 \mathrm{~m}$ & 0 \\
Landsat 5 & 30th April 2007 & $221 / 75$ & $5 / 4 / 3$ & $30 \mathrm{~m}$ & 0 \\
Landsat 5 & 30th April 2007 & $221 / 76$ & $5 / 4 / 3$ & $30 \mathrm{~m}$ & 0 \\
Landsat 8 & 21st September 2017 & $220 / 75$ & $6 / 5 / 4$ & $30 \mathrm{~m}$ & 0 \\
Landsat 8 & 21st September 2017 & $220 / 76$ & $6 / 5 / 4$ & $30 \mathrm{~m}$ & 0 \\
Landsat 8 & 21st September 2017 & $221 / 75$ & $6 / 5 / 4$ & $30 \mathrm{~m}$ & 0 \\
Landsat 8 & 21st September 2017 & $221 / 76$ & $6 / 5 / 4$ & $30 \mathrm{~m}$ & 0 \\
\hline
\end{tabular}

The procedures with different satellites were necessary due to a single satellite's unavailability, but, for both periods, the same spatial resolution of $30 \mathrm{~m}$ was utilized. The periods of April and September were chosen due to the region's agricultural seasonality. The ten-year time gap allowed the study of the landscape temporal patterns over time. 
The LULC mapping was done by visual and manual on-screen digitizing (1:50.000 scale and pixel of $30 \mathrm{~m}$ ) and cataloged according to the classification system proposed by the Land Use Technical Manual from the IBGE [40]. This arrangement organizes the classes and sub-classes of the land use/land cover. Four general classes were included in the primary group, indicating the LULC categories. The secondary level analyzed the types of land uses, and the tertiary level explained and described the land uses themselves (Table 2). Field visits were done to complement, verify, and validate the mapping done remotely.

Table 2. Mapping of the LULC. Source: [40,41].

\begin{tabular}{|c|c|c|}
\hline Class (I) & Type (II) & Description (III) \\
\hline $\begin{array}{l}\text { Anthropic, not } \\
\text { agricultural areas }\end{array}$ & Urban areas & $\begin{array}{l}\text { Urban area and rural developments (industrial } \\
\text { and household) }\end{array}$ \\
\hline \multirow{5}{*}{ Anthropic agricultural areas } & Sugarcane & Cultivation of Saccharum officinarum $L$ \\
\hline & Citrus & Cultivation of Citrus sinensis \\
\hline & Pastures & $\begin{array}{c}\text { An area with the predominance of herbaceous vegetation, } \\
\text { used for extensive livestock farming (native or exotic) }\end{array}$ \\
\hline & Silviculture & Cultivation area of Eucalyptus spp or Pinus spp \\
\hline & Exposed soil (bare soil) & Soil fallow area \\
\hline Vegetation & Vegetation & $\begin{array}{l}\text { An area with a predominance of tree vegetation, with } \\
\text { natural vegetation cover }\end{array}$ \\
\hline Water & Water & Rivers, lakes, ponds, and reservoirs \\
\hline
\end{tabular}

The transition matrix was done on ArcGIS 10.8 on the same scale by comparing the Raster dataset of the LULC for 2007 and 2017 to analyze the regions that displayed changes in the periods studied, verifying how much of the area was converted and how much stayed in the same class.

Urbanity index indices were used to describe the temporal landscape patterns resulting from the influence of anthropogenic land-use processes in the Tiete-Jacare watershed. This method assumes that the relevance of land use and land cover environmental impacts are associated with the vulnerability of environmental components to anthropic disturbances.

The methods in our study were adapted from O'Neill et al., 1988 [10]; Canter, 1996 [42]; Eastman, 1997 [43]; Bojórquez-Tapia et al., 2002 [44]; Wrbka et al., 2004 [11]; and Fritzsons et al., 2004 [45]. Some authors, such as Fushita et al., 2013 [46], Bueno, 2014 [47], and Trevisan; Moschini, 2017 [12], have also developed and tested land use and land cover change indices in the Brazilian context, looking for changes in the landscape caused by urbanization or agriculture over time, mainly due to the decrease of forestry in the different regions of the country.

As with most ecological studies, the data utilized to integrate the landscape had different natures. Thus, it was necessary to standardize the measures using comparability adjustments. We used the fuzzy logic method to analyze the indices to assist with the understanding of the landscape indices. This technique is an extension of Boolean logic, permitting intermediate values between false (0) and true (1). For example, the value could be 0.5 or 0.4 , allowing intermediate states to be treated by control devices $[48,49]$.

The urbanity index (UI) was used to describe the landscape pattern, arising from the influence of anthropogenic processes [10-12] through Equation (1), expressed below:

$$
U I=\log _{10} \frac{(U+A)}{(F+W)}
$$

where $U$ is urban area, $a$ is agriculture, $F$ is vegetation, and $W$ is water.

It was considered that $U I=0$ represented the maximum degree of ease and that $U I=1$ represented the minimum degree of urbanity, corresponding to landscapes predominantly 
altered human systems. In this assessment, larger naturalistic areas correlate with less impacts, and lower urbanity systems correlate with more impacted systems. To help with the understanding of the results, $U I$ data were splits into five classes: 0 to $0.2=$ very low; 0.2 to $0.4=$ low; 0.4 to $0.6=$ medium; 0.6 to $0.8=$ high and 0.8 to $1.0=$ very high.

We considered only vegetation to be the native forest fragments. The plantation of forestry, for example, was considered as agricultural cultivation. This classification is essential to give an accurate characterization of the environmental landscape quality over time. The transition matrix was done on ArcGIS 10.8 by comparing the Raster dataset of the urban index for 2007 and 2017 to analyze the regions that have changes along the periods studied, verifying how much of the area was converted and how much stayed in the same class.

\section{Results}

\subsection{LULC Analysis}

Nine classes of LULC were found: citrus, diverse cultures (because of the satellite image resolution, corn, coffee, and rice were grouped in the same land use), exposed soil, pastures, silviculture, sugarcane, urban, vegetation, and water. The region increased crop activities by $24,507.53$ ha ( $2.05 \%$ of the total area), mainly related to sugarcane cultivation (Figure 3).

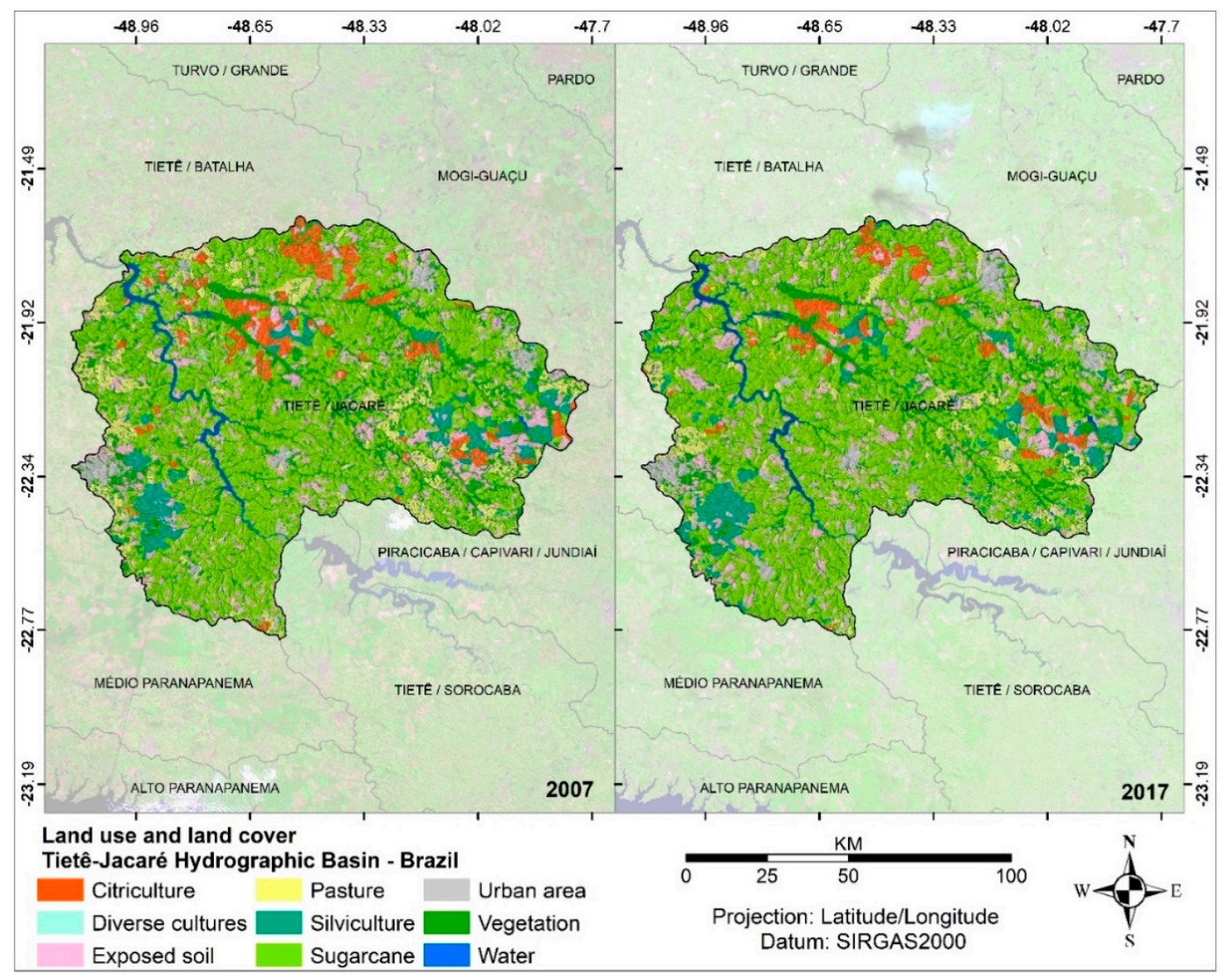

Figure 3. LULC mapping for 2007 and 2017.

The LULC organization presented an association with anthropic activities. It was observed that regions whose agricultural activities occur are already predefined and delimited, even before the periods analyzed. In 2007, approximately $72 \%$ of the area presented a predominance of agricultural activities: 542,114 ha of sugarcane, $49,272.60$ ha of silviculture, $76,817.59$ ha of pasture, $62,121.90$ ha of citrus cultivation, and 1315.71 ha of diverse cultures (Table 3). 
Table 3. LULC class distribution for 2007 and 2017.

\begin{tabular}{ccccc}
\hline \multirow{2}{*}{ Classes } & \multicolumn{2}{c}{ Land Use (2007) } & \multicolumn{2}{c}{ Land Use (2017) } \\
\cline { 2 - 5 } & Area (ha) & \% & Area (ha) & \% \\
\hline Sugarcane & $542,124.00$ & 45.90 & $607,455.00$ & 51.43 \\
Water & $16,955.80$ & 1.44 & $16,764.60$ & 1.42 \\
Citriculture & $62,121.90$ & 5.26 & $38,198.80$ & 3.23 \\
Diverse cultures & 1315.71 & 0.11 & 1382.63 & 0.12 \\
Pastures & $76,817.59$ & 6.50 & $51,564.90$ & 4.37 \\
Silviculture & $49,272.60$ & 4.17 & $58,258.00$ & 4.93 \\
Exposed soil & $122,046.00$ & 10.33 & $121,346.00$ & 10.27 \\
Urban area & $36,148.40$ & 3.06 & $43,981.07$ & 3.72 \\
Vegetation & $274,288.00$ & 23.22 & $242,139.00$ & 20.50 \\
Total & $1,181,090.00$ & 100.00 & $1,181,090.00$ & 100.00 \\
\hline
\end{tabular}

The exposed soil areas (E. soil) are associated with agricultural activities (122,046 ha), referring to soil preparation for the next harvest. In the Tiete-Jacaré region, these areas are associated with sugarcane. The pasture areas appear in small portions around all the watershed and are characterized as a subsistence or small-scale production activity. The areas with sugarcane are predominant in the watershed. Nonetheless, in some regions, the agricultural cultures are dominant, such as citrus cultivation in the Matão, Nova Europa, and Gavião Peixoto regions, and forestry in the Agudos, Pederneiras, Brotas, and Itirapina regions [41].

In 2017, approximately $74 \%$ of the area presented a predominance of agricultural activities: 607,455 ha $(51 \%)$ of sugarcane, 58,258 ha $(4.93 \%)$ of silviculture, $51,564.9$ ha $(4.37 \%)$ of pastures, $38,198.80$ ha $(3.23 \%)$ of citriculture, 1382.63 ha $(0.12 \%)$ of diverse cultures, and 121,346 ha (10.27\%) of exposed soil. Compared to 2007, a growth of 65,331 ha of sugarcane crops was observed, and areas of other agricultural uses were also converted.

Urban areas increased by $21.68 \%$ or 7832.67 ha, and it is was more noticeable in medium and large municipalities, such as Bauru, Jaú, Araraquara, and São Carlos. The smaller cities such as Ribeirão Bonito, Torrinha, and Brotas still maintained their socioeconomic structures focused on agricultural activities, having technical support from the medium and larger cities [41].

The vegetation areas appear fragmented and are immersed in the agricultural matrix, displaying a loss of $2.7 \%(32,149 \mathrm{ha})$ in the period analyzed. The vegetation remnants are located near the main rivers, for example, the Tietê-Jacaré river in the Itajú, Bariri, Ibitinga, and Bocaina municipalities; the Jacaré-Guaçu river in the Ribeirão Bonito, São Carlos, Ibaté and Itirapina municipalities; and the Jacaré-Pepira river in the Dourado and Brotas and Rio Jaú municipalities.

The transition matrix (Table 4) showed an alteration of $34.70 \%$ in the Tietê-Jacaré watershed landscape between 2007 and 2017. The exposed soil areas suffered the most changes $(85.10 \%)$ due to their fallow characteristics for other uses. The transition characteristics were similar in all regions of the watershed, mainly due to the predominance of sugarcane activities, which directed the different fragments of the landscape to be converted to such cultivation.

Agricultural uses also changed, such as citrus $(62.90 \%)$, pasture $(67 \%)$, forestry $(40.30 \%)$, and sugarcane $(22.20 \%)$. Some of these areas have either become fallow or no-till areas for sugarcane cultivation. The natural regions changed $36.4 \%$, converted between other uses, although some areas were recovered (Table 5).

The most significant transitions in the watershed region are related to converting areas with natural vegetation to the cultivation of sugarcane (in almost all the municipalities), totaling 43.881 ha over the ten years. However, in the various regions, the recovery of agricultural areas to vegetation occurred. During this period, the restoration or recovery of large areas did not happen, but rather small fragments throughout the landscape. 
Table 4. The transition data of the LULC.

\begin{tabular}{ccccc}
\hline Land Use & $\begin{array}{c}\text { Hectares } \\
\text { in 2007 }\end{array}$ & $\begin{array}{c}\text { Hectares } \\
\text { Kept in 2017 }\end{array}$ & $\begin{array}{c}\text { Hectares } \\
\text { Converted in 2017 }\end{array}$ & $\begin{array}{c}\text { \% Hectares } \\
\text { Converted }\end{array}$ \\
\hline Sugarcane & $542,124.00$ & $421,977.14$ & $120,146.86$ & 22.20 \\
Water & $16,955.80$ & $16,764.60$ & 191.20 & 1.10 \\
Citriculture & $62,121.90$ & $23,037.40$ & $39,084.50$ & 62.90 \\
Diverse cultures & 1315.71 & 1315.71 & 0.00 & 0.00 \\
Pastures & $76,817.59$ & $24,744.32$ & $52,073.27$ & 67.80 \\
Silviculture & $49,272.60$ & $29,396.77$ & $19,875.83$ & 40.30 \\
Exposed soil & $122,046.00$ & $18,230.60$ & $103,815.40$ & 85.10 \\
Urban area & $36,148.40$ & $36,148.40$ & 0.00 & 0.00 \\
Vegetation & $274,288.00$ & $199,764.83$ & $74,523.17$ & 27.20 \\
\hline Total & $1,181,090.00$ & $771,379.77$ & $409,710.23$ & 34.70 \\
\cline { 2 - 4 } & & \multicolumn{2}{c}{$1,181,090.00$} \\
\hline
\end{tabular}

Table 5. Distribution data of the LULC transition.

\begin{tabular}{|c|c|c|c|c|c|}
\hline \multicolumn{2}{|c|}{ Transition (2007/2017) } & \multirow{2}{*}{$\begin{array}{l}\text { Area (ha) } \\
421,977.14\end{array}$} & \multicolumn{2}{|c|}{ Transition (2007/2017) } & \multirow{2}{*}{$\begin{array}{c}\text { Area (ha) } \\
1921.98\end{array}$} \\
\hline Sugarcane & Sugarcane & & Pasture & Urban & \\
\hline Sugarcane & Citriculture & 5944.67 & Pasture & Vegetation & 7765.59 \\
\hline Sugarcane & Pasture & 9834.27 & Silviculture & Sugarcane & 5935.15 \\
\hline Sugarcane & Silviculture & $10,181.10$ & Silviculture & Citriculture & 904.11 \\
\hline Sugarcane & Exposed soil & $72,449.10$ & Silviculture & Pasture & 1020.50 \\
\hline Sugarcane & Urban & 2373.09 & Silviculture & Silviculture & $29,396.77$ \\
\hline Sugarcane & Vegetation & $19,364.63$ & Silviculture & Exposed soil & 7152.34 \\
\hline Water & Sugarcane & 67.22 & Silviculture & Urban & 48.23 \\
\hline Water & Water & $16,764.60$ & Silviculture & Vegetation & 4815.50 \\
\hline Water & Citriculture & 0.51 & Exposed soil & Sugarcane & $77,737.30$ \\
\hline Water & Pasture & 40.19 & Exposed soil & Citriculture & 5868.57 \\
\hline Water & Silviculture & 21.00 & Exposed soil & Pasture & 6110.23 \\
\hline Water & Exposed soil & 0.61 & Exposed soil & Silviculture & 6929.36 \\
\hline Water & Urban & 16.71 & Exposed soil & Exposed soil & $18,230.60$ \\
\hline Water & Vegetation & 44.97 & Exposed soil & Urban & 557.08 \\
\hline Citriculture & Sugarcane & $25,698.81$ & Exposed soil & Vegetation & 6612.87 \\
\hline Citriculture & Citriculture & $23,037.40$ & Urban & Urban & $36,148.40$ \\
\hline Citriculture & Pasture & 541.94 & Diverse uses & Diverse uses & 1315.71 \\
\hline Citriculture & Silviculture & 1386.02 & Vegetation & Sugarcane & $43,881.30$ \\
\hline Citriculture & Exposed soil & 7847.92 & Vegetation & Citriculture & 2098.69 \\
\hline Citriculture & Urban & 289.77 & Vegetation & Pasture & 9198.46 \\
\hline Citriculture & Vegetation & 3311.06 & Vegetation & Silviculture & 6953.22 \\
\hline Pasture & Sugarcane & $32,197.40$ & Vegetation & Exposed soil & 9302.40 \\
\hline Pasture & Citriculture & 350.02 & Vegetation & Urban & 3022.18 \\
\hline Pasture & Pasture & $24,744.32$ & Vegetation & Diverse uses & 66.92 \\
\hline Pasture & Silviculture & 3347.49 & Vegetation & Vegetation & $199,764.83$ \\
\hline Pasture & Exposed soil & 6490.80 & & & \\
\hline
\end{tabular}

The predominance of sugarcane also meant that other agricultural uses were converted to this crop (pasture (32,197.40 ha), citriculture (25,698.81 ha), and silviculture (5935.15 ha). This activity is consolidated in the region, structuring the region's economic sector, and thus some warnings are necessary in relation to the monopolization of sugarcane and the conservation of natural ecosystems. For example, burning sugarcane straw causes organic matter oxidation and eliminates some pests' natural predators.

\subsection{Urbanity Index Analysis}

The UI analysis (Figure 4) showed (Table 6) an increased process of landscape modification between 2007 and 2017 associated with the expansion of anthropic activities in the region, headed by agricultural activities. The decrease of the landscape environmental 
quality reflects negative impacts on the ecosystems' goods and services and landscape structure. A fragments loss was observed with high environmental quality $(U I=0$ to 0.2$)$, growing in areas with values of 0.2 to 0.4 .

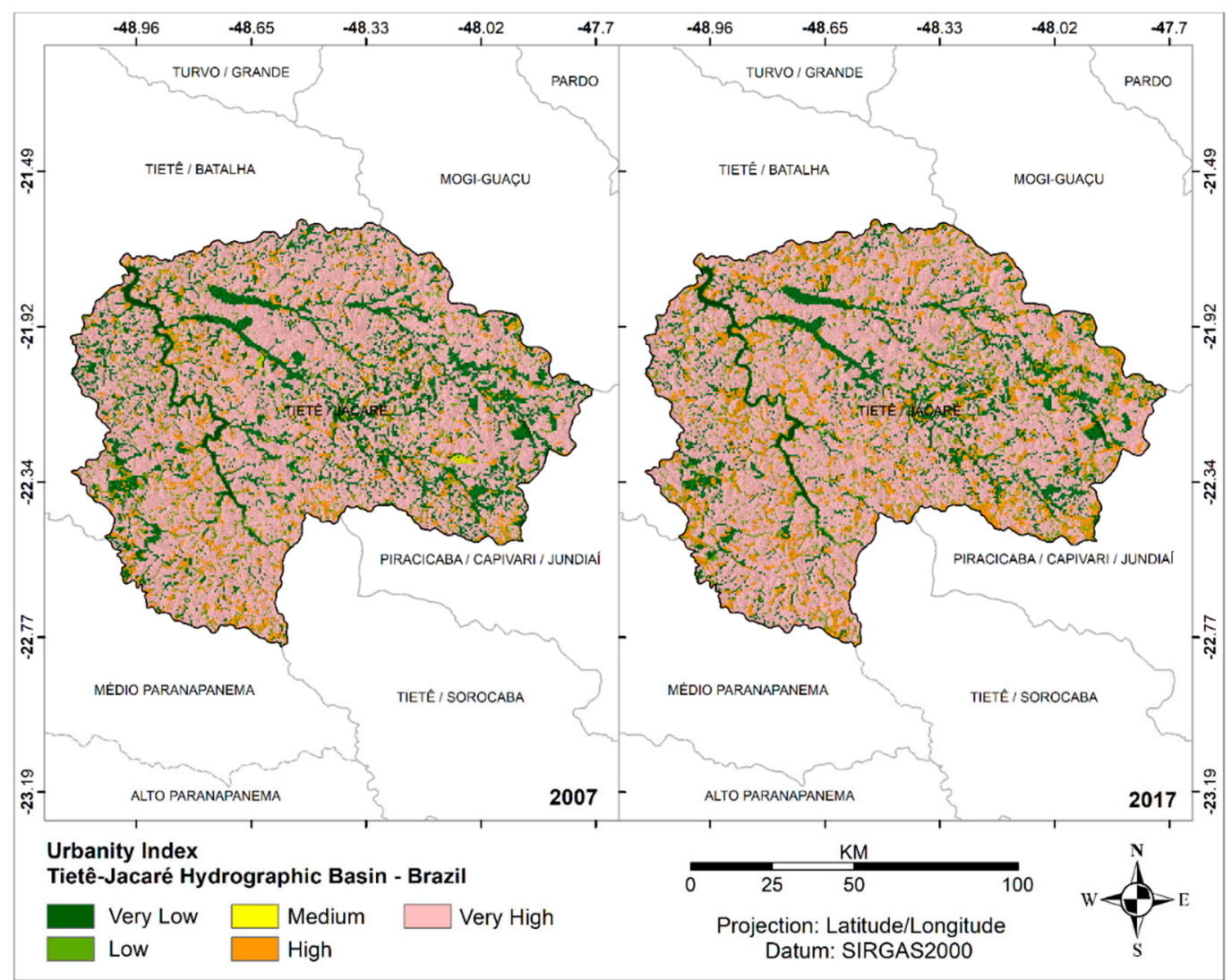

Figure 4. UI classification for 2007 and 2017.

Table 6. UI values for 2007 and 2017.

\begin{tabular}{ccccccc}
\hline \multirow{2}{*}{ Classes } & \multicolumn{2}{c}{$U I$ (2007) } & \multicolumn{2}{c}{$U I$ (2017) } & \multicolumn{2}{c}{ Changes } \\
\cline { 2 - 7 } & Area (ha) & \% & Area (ha) & \% & Area (ha) & \% \\
\hline $0.0-0.2$ & $218,058.00$ & 18.46 & $155,160.00$ & 13.14 & $-62,898.00$ & -28.84 \\
$0.2-0.4$ & $49,836.90$ & 4.22 & $78,303.10$ & 6.63 & $28,466.20$ & 57.12 \\
$0.4-06$ & 5612.10 & 0.48 & 5351.90 & 0.45 & -260.20 & -4.64 \\
$0.6-0.8$ & $107,516.00$ & 9.10 & $159,511.00$ & 13.51 & $51,995.00$ & 48.36 \\
$0.8-1.0$ & $800,067.00$ & 67.74 & $782,764.00$ & 66.27 & $-17,303.00$ & -2.16 \\
Total & $1,181,090.00$ & 100.00 & $1,181,090.00$ & 100.00 & - & - \\
\hline
\end{tabular}

However, this increase is related to the conversion of the fragments with high quality that decreased in area over the study period. Almost all the fragments with very high or high environmental quality $(U I=0$ to 0.4$)$, according to the index, are close to the water or areas with a high slope with limited potential for any human activity. Therefore, these conditions imply the loss of landscape parameters such as connectivity, total size, perimeter, shape, and border.

UI values of 0.4 to 0.6 represent a natural landscape scenario and could only be identified in some regions of the watershed. These regions are associated with fragments that are still conserved or restored but continue to be impacted by pressures due to their proximity to anthropic activities, thus becoming susceptible to suffer changes over time (Figure 5). 


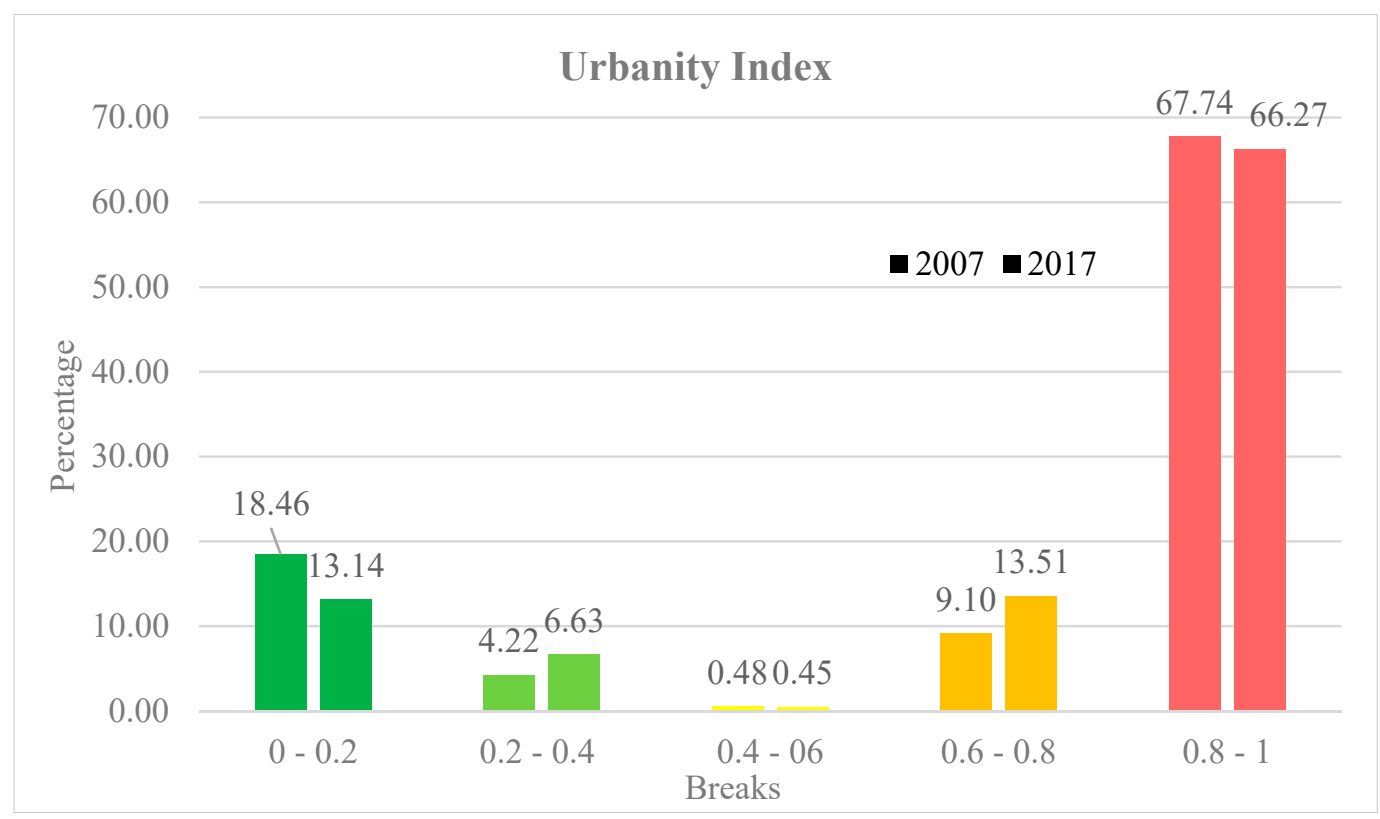

Figure 5. Variation of UI values for 2007 and 2017.

The results also show that most of the fragments are in the very high urbanity interval of $U I=0.8$ to 1 . From an ecological perspective, this is a consequence of the vegetation loss that occurred before the period analyzed and demonstrates the severe condition of the region due to the pressure of anthropic activities. It is essential to highlight that, even when fragmented in the landscape, the vegetation areas preserve a crucial role concerning the environmental goods and services provided by these areas, such as regulation, production, and support, critical for anthropic maintenance and development activities.

The urbanity index (Table 7) transition matrix showed an alteration of $32.47 \%$ in the Tietê-Jacaré watershed landscape between 2007 and 2017. The high classes suffered the most changes $(69.75 \%)$. The transition characteristics were similar in all watershed regions, mainly due to the increase and predominance of anthropic activities over time.

Table 7. The evolution of the urbanity index.

\begin{tabular}{ccccc}
\hline IB & $\begin{array}{c}\text { Hectares } \\
\text { in 2007 }\end{array}$ & $\begin{array}{c}\text { Hectares } \\
\text { Kept in 2017 }\end{array}$ & $\begin{array}{c}\text { Hectares } \\
\text { Converted in 2017 }\end{array}$ & $\begin{array}{c}\text { \% Hectares } \\
\text { Converted }\end{array}$ \\
\hline Very low & $218,058.00$ & $109,972.73$ & $108,085.27$ & 49.57 \\
\hline Low & $49,836.90$ & $16,042.34$ & $33,794.56$ & 67.81 \\
\hline Medium & 5612.10 & 5351.10 & 261.00 & 4.65 \\
\hline High & $107,516.00$ & $32,521,85$ & $74,994.15$ & 69.75 \\
\hline Very High & $800,067.00$ & $633,656.12$ & $166,410.88$ & 20.80 \\
\hline \multirow{2}{*}{ Total } & $1,181,090.00$ & $797,544.14$ & $383,545.86$ & 32.47 \\
\cline { 2 - 5 } & & \multicolumn{2}{c}{$1,181,090.00$} \\
\hline
\end{tabular}

The very low and low classes also had considerable changes, with 49.57 and $67.81 \%$, respectively (Table 8). The most significant transitions in the watershed region are related to the conversion of areas with very high into high intervals, totaling 104,209.00 ha in ten years.

However, in the various regions, a 33,129.60 ha change from very high to very low intervals was observed, indicating positive reforestation practices. However, as mentioned, during this period, the restoration or recovery of large areas did not occur, but rather this happened with small fragments throughout the landscape. 
Table 8. Distribution of urbanity index transition.

\begin{tabular}{cccccc}
\hline \multicolumn{2}{l}{ Transition } & (2007/2017) & Area (ha) & \multicolumn{2}{c}{ Transition } \\
\hline High & High & $32,521.85$ & Medium & Medium & Area (ha) \\
High & Low & 4857.92 & Very high & High & $104,209.00$ \\
High & Medium & 378.73 & Very high & Low & $27,801.20$ \\
High & Very high & $65,295.30$ & Very high & Medium & 1271.08 \\
High & Very low & 4462.20 & Very high & Very high & $633,656.12$ \\
Low & High & 6426.99 & Very high & Very low & $33,129.60$ \\
Low & Low & $16,042.34$ & Very low & Low & $29,455.10$ \\
Low & Medium & 488.56 & Very low & High & $16,244.70$ \\
Low & Very high & $19,229.60$ & Very low & Medium & 392.37 \\
Low & Very low & 7649.41 & Very low & Very high & $61,993.10$ \\
Medium & High & 261.00 & Very low & Very low & $109,972.73$ \\
\hline
\end{tabular}

\section{Discussion}

The predominance of sugarcane observed in our study overlaps with the region and the São Paulo history as a whole, principally as the largest sugarcane producer in Brazil. Favorable conditions provide fertile soils that allow productivity to be higher than in other regions [50,51]. As we evidenced, this expansion of sugarcane cultivation areas is similar to studies carried out with this same theme in different regions [21,52].

The transition between cultivation areas and exposed soil reinforces the importance of the periods chosen to analyze LULC, principally when the study works with seasonal activities, as is the case in the Tiete-Jacaré region, where the periods of April and September demonstrates lees transitions between cops and exposed soil and thus are more easily analyzed. We did the mapping manually, however, using automatic classification could change the scenario's perspective.

The vegetation loss and growth of agriculture over time were also studied by Moraes (2013) [53], Mello (2014) [54], and Inkoom et al. (2018) [55], which also analyzed the vegetation biomes of Cerrado and Seasonal Semideciduous Forest, evidencing the fragmentation process due to anthropic activities. Additionally, other regions in the country present the same results. The study conducted by Silva et al. (2020) [56] revealed a vegetation loss of $10 \%$ between 2015 and 2018 in the Cuite municipality, located in the Paraiba state in the northwest of Brazil. After the Amazon biome, the regions that suffer the most from anthropic changes in Brazil are the Brazilian Savanna (Cerrado) and the Atlantic Forest. The Cerrado is the second largest biome in South America, occupying 2,036,448 $\mathrm{km}^{2}$, about $22 \%$ of the national territory. The Atlantic Forest covers about $15 \%$ of the national territory, with a concentration of about $72 \%$ of Brazilians and $70 \%$ of the gross domestic product (GDP), leaving only $12.4 \%$ of the original forest. These impacts compromise all environmental structures and services and have impacts on soils that support vegetation cover and significant energy sources for terrestrial life $[21,57,58]$.

Figure 6 shows the LULC changes and tree frames from an amplified region of the watershed. It is possible to see the loss of vegetation fragments and the predominance of sugarcane (in light red) under all the other land use classes and land cover and how this increases visually over time. Additionally, Figure 7 shows the same frame but from the perspective of the urbanity index. It is possible to see the changes and the grown of the urbanized classes in the same areas where the anthropogenic activities increase. The vegetation area was lost in the periods analyzed. In this way, it is possible to affirm that LULC configuration and distribution directly relate to the landscapes' environmental quality (some field photos could be seen in the Supplementary Materials). 


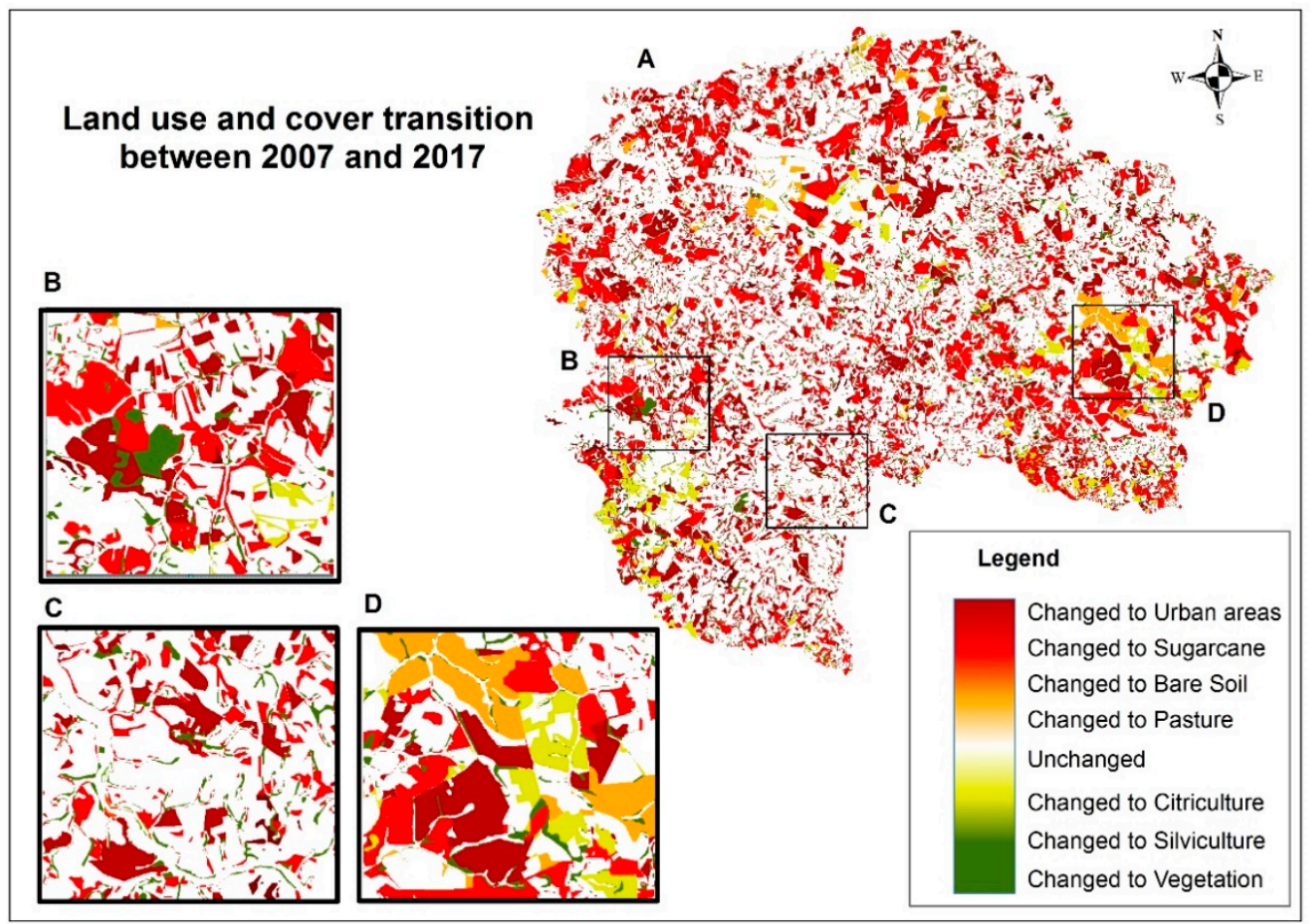

Figure 6. The LULC transition ( $\mathrm{A}=$ Tiete-Jacaré region; $\mathrm{B}=$ (fragments with the transition to vegetation; $\mathrm{C}=$ fragments with the transition to urban areas and $\mathrm{D}=$ fragments with the transition to agriculture areas).

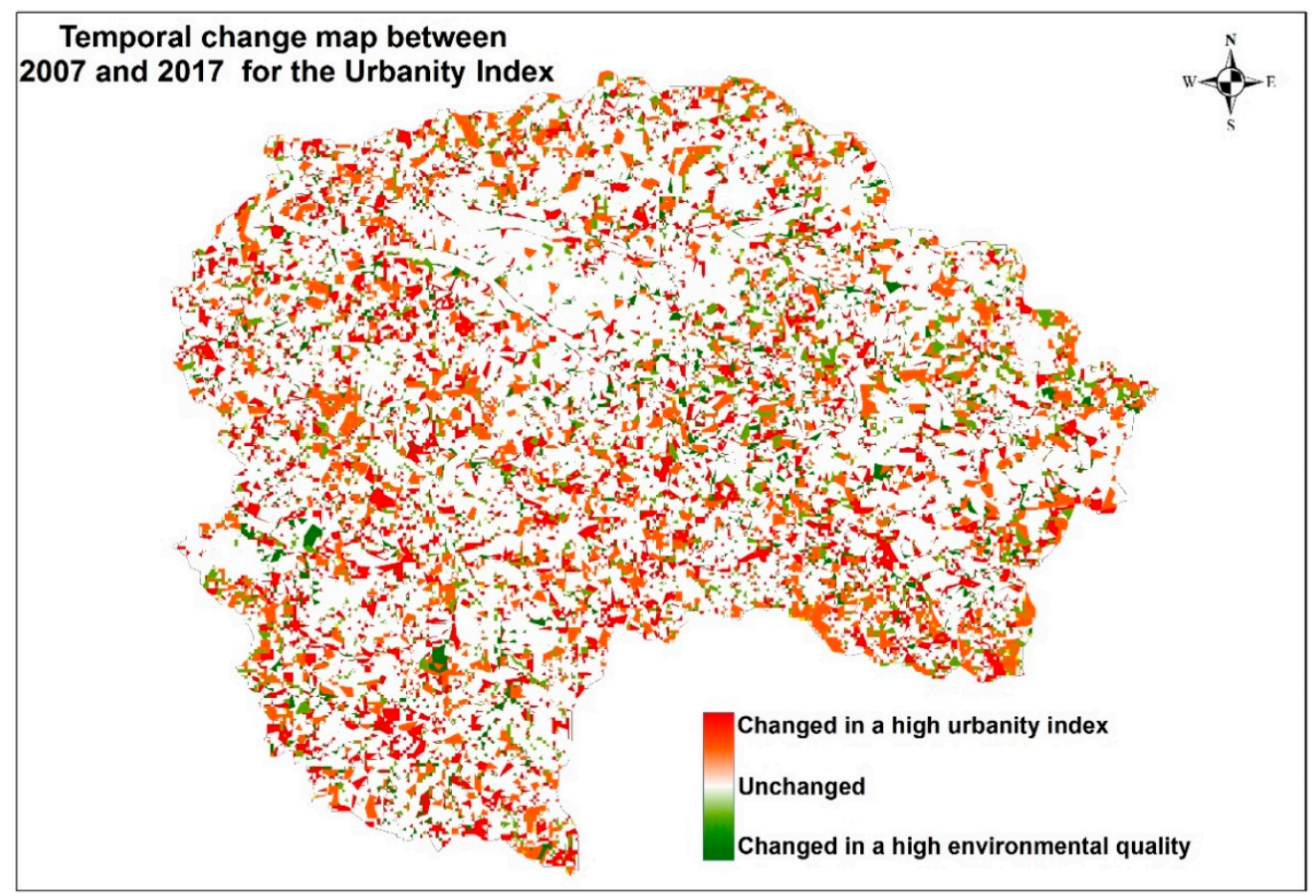

Figure 7. UI cover transition.

According to the Brazilian Institute of Geography and Statistics (IBGE) (2016) [40], in 2007, the Brazilian sugarcane crop was approximately 428 million tons and increased to about 650 million tons in 2017. This scenario corroborates the context found in our study region and has contributed to the growth of $U I$ values and the loss of the landscape's natural conditions. 
Many authors discuss the LULC transition's impacts from natural or even agricultural fragments to sugarcane or other crop monocultures [59-62]. As Zimmermann (2009) [63] states, "the simplification of ecosystems, an indispensable process for the development of extensive monoculture, is extremely dangerous for the maintenance of those that are, in general, complex." Unplanned LULC management has led the Brazilian regions to numerous environmental issues, such as soil contamination, decreased infiltration of rainwater, and increased runoff. This set of factors favors the intensification of the water erosion process, which can evolve to the laminar, groove, or ravine form [56,64].

This scenario is observed in the Tietê-Jacare watershed, where the loss of the natural landscape consequently has created a naturalness similar to that observed in the studies by Moschini (2008) [65], Dos Santos (2011) [66], Fushita et al. (2016) [67], Trevisan; Moschini (2016) [21], and Trevisan et al. (2018) [28]. These authors also evidenced the loss of natural vegetation areas and the consequent increase of impacts on Brazil's other regions. Trevisan; Moschini (2017) [12] focused on analyzing the temporal dynamics of LULC in Americana city in São Paulo state, Brazil in 1994, 2008, and 2016. They also aimed to diagnose landscape urbanity through the application of the urbanity index (UI). The results also evidenced an increase in landscape urbanization over time, mainly due to the region's forests decrease.

Some studies also disused the landscape changes in the European context and their impacts on the modification on LULC [68-70]. The study conducted by Moravcová et al. (2016) [71] covered nineteen areas in the western part of the Czech Republic that were affected by land consolidation processes during 2000-2006. They aimed to document how land consolidation processes could affect land use and landscape structure and whether the land consolidation planners considered the protection of natural resources. The authors found that the increased acreage of grasslands was the most significant change in land use in the region, before and after land consolidations, and involved $6.8 \%$ of the total land consolidation area.

Development planning and management that considers the conservation and development of all ecosystems (anthropic and natural), focused on conserving natural resources, has become necessary. The conception of zoning strategies must integrate the land use relation and land cover occupation with natural landscapes. The process of landscape development and changes has been occurring intensely, and it is necessary for urgent actions to maintain, protect, and recover vegetation areas. Thus, the ecosystems can continue to provide goods and services to our planet, providing the possibility of an excellent quality of life in society and the meeting of socio-economic needs.

\section{Conclusions}

As expected, the presence or absence of vegetation alters and is directly related to the landscapes' environmental quality. The vegetation reduction of 32,149 ha $(2.72 \%)$ between 2007 and 2017 resulted in the loss of the landscape naturalness in the Tietê-Jacaré watershed. This loss is small in terms of percentages, but in ecological terms, this is a considerable loss that has changed the landscape's quality in some watershed regions. The region needs an environmental and urban plan that aims to maintain and restore the vegetation, giving priority to the conservation of these areas, considering the current state of the region and the developmental trend that has been followed and solidified over the years.

However, it is emphasized that the analysis of fragmentation and connectivity must always be contextualized, and its discussions are based on the scale of analysis used as this may imply changes in the observation of studies. For example, the present research worked with the spatial resolution of $30 \mathrm{~m}$, that is, 1:50,000. Thus, the analyses of LULC dynamics were performed on this scale. The same analyzes can change at smaller scales and with greater richness of details or lose information if performed at larger scales and with a lesser richness of details.

The increase of participation spaces through social mobilization and its representability should be a governmental administration premise. The formulation and execution of 
plans, programs, and projects should also be adapted to the local reality and thus fulfill its objectives, proposing integrated management between government and society. Additionally, the forest legislation application, as the Brazilian Forest Code, should be followed by the population and applied by the inspectors, ensuring the efficacy of the environmental instrument, and more regulations and legislation should be under discussion to organize the distribution and interaction of the anthropic activities and forests in the country.

The urbanity index expresses the conservation and naturalness state of the landscape studied. It is presented as an essential tool for the diagnosis of the environment and for the conservation of the ecosystem, allowing precise analysis of landscape elements and enabling accurate analysis of each fragment of the landscape.

Supplementary Materials: The following are available online at https:/ / www.mdpi.com/2071-105 0/13/6/3021/s1, Figure S1: LULC transition for 2007 and 2017, Figure S2: UI cover transition for 2007 and 2017, Figure S3: Land use and land rate (\%) for 2007 and 2017, Figure S4: UI rate (\%) for 2007 and 2017, Figure S5: Sugarcane and exposed soil areas ( $\left.-21^{\circ} 58^{\prime} 45.16^{\prime \prime} ;-48^{\circ} 0^{\prime} 5.21^{\prime \prime}\right) — 09 / 05 / 2019$. Field photos of the Tiete-Jacaré watershed region, Figure S6: Spring near to sugarcane $\left(-21^{\circ} 58^{\prime} 44.80^{\prime \prime}\right.$; $\left.-48^{\circ} 0^{\prime} 5.27^{\prime \prime}\right)-09 / 05 / 2019$, Figure S7: Citriculture cultivation areas $\left(-22^{\circ} 22^{\prime} 47.27^{\prime \prime} ;-48^{\circ} 07^{\prime} 33.26^{\prime \prime}\right)$ 10/10/2019, Figure S8: Pasture and forestry areas $\left(-22^{\circ} 25^{\prime} 42.12^{\prime \prime} ;-48^{\circ} 10^{\prime} 54.29^{\prime \prime}\right)-10 / 10 / 2019$, Figure S9: Tietê river dam in Barra Bonita municipality $\left(-22^{\circ} 31^{\prime} 10^{\prime \prime} ;-48^{\circ} 32^{\prime} 04^{\prime \prime}\right)$ [72], Figure S10: Jacaré-Pepira river in Brotas municipality (-22 $\left.17^{\prime} 33.67^{\prime \prime} ;-48^{\circ} 07^{\prime} 46.08^{\prime \prime}\right)-11 / 10 / 2019$.

Author Contributions: Conceptualization, D.P.T. and L.E.M.; Data curation, D.P.T. and P.d.C.B.; Formal analysis, D.P.T., P.d.C.B., D.A., and M.H.R.; Funding acquisition, D.P.T. and L.E.M.; Investigation, D.P.T. and P.d.C.B.; Methodology, D.P.T. and P.d.C.B.; Project administration, D.P.T., P.d.C.B., L.E.M., and H.B.; Resources, D.P.T., L.E.M., and H.B.; Software, D.P.T., P.d.C.B., and M.H.R.; Supervision, L.E.M. and H.B.; Validation, D.P.T., P.d.C.B., and M.H.R.; Visualization, D.P.T. and P.d.C.B.; Writingoriginal draft, D.P.T., D.A., P.d.C.B., M.I., L.E.M., and H.B.; Writing-review \& editing, D.P.T., D.A., P.d.C.B., M.I., L.E.M., M.H.R., and H.B. All authors have read and agreed to the published version of the manuscript.

Funding: This research was funding by the São Paulo Research Support Foundation (FAPESP process n 2015/19918-3 and 2018/00162-4); the European Union's Horizon 2020 Research and Innovation Programme (Marie Skłodowska-Curie grant $\left.n^{\circ} 660020\right)$; the Royal Society Wolfson Research Merit Award (2011/R3); and the Natural Environment Research Council and National Centre for Earth Observation.

Institutional Review Board Statement: Not applicable.

Informed Consent Statement: Not applicable.

Data Availability Statement: The data is available in the Federal University G-Suit (Google Drive Storage): https://drive.google.com/file/d/10Fqkh_w0LkZ2EU3XgqJgrCY6ZG-qd0Uq/view?usp= sharing.

Conflicts of Interest: The authors declare no conflict of interest. The funders had no role in the design of the study; in the collection, analyses, or interpretation of data; in the writing of the manuscript, or in the decision to publish the results.

\section{References}

1. Ridding, L.E.; Newton, A.C.; Redhead, J.W.; Watson, S.C.L.; Rowland, C.S.; Bullock, J.M. Modelling historical landscape changes. Landsc. Ecol. 2020, 35, 2695-2712. [CrossRef]

2. Intergovernmental Painel on Climate Change. Climate Change 2007: Synthesis Report, 1st ed.; IPCC: Geneva, Switzerland, 2007; 976p.

3. Marques, A.; Martins, I.S.; Kastner, T.; Plutzar, C.; Theurl, M.C.; Eisenmenger, N.; Huijbregts, M.A.J.; Wood, R.; Stadler, K.; Bruckner, M.; et al. Increasing impacts of land use on biodiversity and carbon sequestration driven by population and economic growth. Nat. Ecol. Evol. 2019, 3, 628-637. [CrossRef] [PubMed]

4. Chaichi, N.; Daim, T.U. Landscape Analysis: Connected Lighting System. Innov. Technol. Knowl. Manag. 2018, 1, 45-65. [CrossRef]

5. Song, X.-P.; Hansen, M.C.; Stehman, S.V.; Potapov, P.V.; Tyukavina, A.; Vermote, E.F.; Townshend, J.R. Global land change from 1982 to 2016. Nat. Cell Biol. 2018, 560, 639-643. [CrossRef]

6. Weiberg, E.; Hughes, R.E.; Finné, M.; Bonnier, A.; Kaplan, J.O. Mediterranean land use systems from prehistory to antiquity: A case study from Peloponnese (Greece). J. Land Use Sci. 2019, 14, 1-20. [CrossRef] 
7. United Nations. UN Agenda 2030. Available online: https://sdgs.un.org/2030agenda (accessed on 26 October 2020).

8. Gardner, R.H.; O'Neill, R.V. Pattern, process, and predictability: The use of neutral models for landscape analysis. In Quantitative Methods in Landscape Ecology: The Analyses and Interpretation of Landscape Heterogeneity, 1st ed.; Turner, G.M., Gardner, R.H., Eds.; Springer: New York, NY, USA, 1991; pp. 289-308.

9. Van Zanten, B.T.; Van Berkel, D.B.; Meentemeyer, R.K.; Smith, J.W.; Tieskens, K.F.; Verburg, P.H. Continental-scale quantification of landscape values using social media data. Proc. Natl. Acad. Sci. USA 2016, 113, 12974-12979. [CrossRef]

10. O'Neillr, R.V.; Krummel, J.R.; Gardner, R.H.; Sugihara, G.; Jackson, B.; DeAngelist, D.L.; Milne, B.T.; Turner, M.G.; Zygmunt, B.; Christensen, S.W.; et al. Indices of landscape pattern. Landsc. Ecol. 1988, 1, 153-162. [CrossRef]

11. Wrbka, T.; Erb, K.-H.; Schulz, N.B.; Peterseil, J.; Hahn, C.; Haberl, H. Linking pattern and process in cultural landscapes. An empirical study based on spatially explicit indicators. Land Use Policy 2004, 21, 289-306. [CrossRef]

12. Trevisan, D.P.; Moschini, L.E. Evaluation of landscape urbanity in Americana, São Paulo, Brazil. Int. J. Dev. Res. 2017, 7, 1617716183. Available online: https://www.journalijdr.com/evaluation-landscape-urbanity-americana-s\%C3\%A3o-paulo-brazil (accessed on 10 January 2021).

13. O'Sullivan, D.; Bergmann, L.; Thatcher, J.E. Spatiality, Maps, and Mathematics in Critical Human Geography: Toward a Repetition with Difference. Prof. Geogr. 2017, 70, 129-139. [CrossRef]

14. Ritters, K.H.; O’Neil, R.V.; Hunsaker, C.T.; Wickham, J.D.; Yankee, D.H.; Timmins, S.P. A factor analysis of landscape pattern and structure metrics. Landsc. Ecol. 1995, 10, 23-39. [CrossRef]

15. Baró, F.; Baggethun, E.G.; Haase, D. Ecosystem service bundles along the urban-rural gradient: Insights for landscape planning and management. Ecosyst. Serv. 2017, 24, 147-159. [CrossRef]

16. Turner, M.G. Spatial simulation of landscape changes in Georgia: A comparison of 3 transition models. Landsc. Ecol. 1987, 1, 29-36. [CrossRef]

17. Gustafson, E.J.; Parker, G.R. Relationships between landcover proportion and indices of landscape spatial pattern. Landsc. Ecol. 1992, 7, 101-110. [CrossRef]

18. Mcgarigal, K.; Marks, B. Fragstats Manual. 1995. Available online: www.innovativegis.com/products/fragstatsarc/manual/ index.html (accessed on 25 April 2020).

19. Schumaker, N.H. Using Landscape Indices to Predict Habitat Connectivity. Ecology 1996, 77, 1210-1225. [CrossRef]

20. Moretti, R.S. Content and procedures for preparing master plans. In Municipal Master Plans-New Concepts of Territorial Planning (Org); Bueno, L.M.M., Cymbalista, R., Eds.; Annablume: São Paulo, Brazil, 2007; pp. 265-271.

21. Trevisan, D.P.; Moschini, L.E.; Moraes, M.C.P. Evaluation of the Naturalness of the Landscape in the Municipality of Ibaté, São Paulo, Brazil; Geografia-Rio Claro: Rio Claro, Brazil, 2016; pp. 467-482. Available online: https:/ / www.periodicos.rc.biblioteca.unesp. br/index.php/ageteo/article/view/12646 (accessed on 10 January 2021).

22. Trevisan, D.P. Analysis of Environmental Variables Caused by Land Use Changes and Land Cover in São Carlos, São Paulo, Brazil. São Carlos, 80f. Master's Thesis, Federal University of São Carlos, São Paulo, Brazil, 2015.

23. Turner, M.G.; Gardner, R.H. Quantitative Methods in Landscape Ecology, 1st ed.; Springer: New York, NY, USA, $1991 ;$ p. 536.

24. Marino, D.; Di Cavallo, A.; Donato, B.D.; Nofroni, L.; Savelli, S. Between Resilience and Sense of Place: Understanding the Agricultural Traditional Landscape. Uniscape En-Route 2015, 1, 66-72.

25. Bellón, B.; Blanco, J.; De Vos, A.; Roque, F.D.O.; Pays, O.; Renaud, P. Integrated Landscape Change Analysis of Protected Areas and their Surrounding Landscapes: Application in the Brazilian Cerrado. Remote Sens. 2020, 12, 1413. [CrossRef]

26. Brasil. In Law $n^{\circ}$ 12.651/2013; 2013. Available online: www.planalto.gov.br/ccivil_03/_Ato2011-2014/2012/Lei/L12651.htm (accessed on 13 May 2020).

27. Duffy, J.E.; Godwin, C.M.; Cardinale, B.J. Biodiversity effects in the wild are common and as strong as key drivers of productivity. Nat. Cell Biol. 2017, 549, 261-264. [CrossRef] [PubMed]

28. Trevisan, D.P.; Moschini, L.E.; Guerrero, J.V.R. Dinâmica Temporal do Uso e Cobertura da Terra no Município de Brotas-SP entre os Anos de 1988 e 2016. Front. J. Soc. Technol. Environ. Sci. 2018, 6, 204-219. [CrossRef]

29. Franklin, J.F.; Forman, R.T.T. Creating landscape patterns by forest cutting: Ecological consequences and principles. Landsc. Ecol. 1987, 1, 5-18. [CrossRef]

30. Turner, M.; Simard, M. Using Spatial Statistics and Landscape Metrics to Compare Disturbance Mosaics. In Learning Landscape Ecology: A Practical Guide to Concepts and Techniques, 1st ed.; Gergel, S.E., Tuner, M.G., Eds.; Springer: London, UK, 2017 ; pp. 175-190.

31. Ribeiro, F.L.; Campos, S.; Piroli, E.L.; Santos, T.G.; Cardoso, L.G. Land use of Alto rio pardo, obtained from visual analysis. In Annals. I Ciclo de Atualização Florestal do Conesul Santa Maria; UFSM: Santa Maria, Brazil, 1999; pp. 75-78.

32. McRae, B.H.; Beier, P. Circuit theory predicts gene flow in plant and animal populations. Proc. Natl. Acad. Sci. USA 2007, 104, 19885-19890. [CrossRef] [PubMed]

33. Tundisi, J.G.; Matsumura-Tundisi, T.; Pareschi, D.C.; Luzia, A.P.; Von Haeling, P.H.; Frollini, E.H. The Tietê-Jacaré Watershed: A case study in research and management. Adv. Stud. 2008, 22, 159-172.

34. CBH-TJ. Report on the Situation of Water Resources in the Tiete Jacaré River Basin Plan, São Paulo: Advanced StudiesState Water Resources Foundation, Final Report, CD-ROM; São Paulo State: São Paulo, Brazil, 2017.

35. São Paulo. State Law n`7.663, de 30/12/1991. Available online: https://www.al.sp.gov.br/repositorio/legislacao/lei/1991/lei7663-30.12.1991.html (accessed on 26 October 2020). 
36. São Paulo. State Law n ${ }^{\circ}$ 9.034, de 27/12/1994. Available online: https://www.al.sp.gov.br/repositorio/legislacao/lei/1994/lei9034-27.12.1994.html (accessed on 26 October 2020).

37. CBH-SM. Water Resources Management Unit. 2015. Available online: www.comitesm.sp.gov.br/institucional.php?k=ugrhi (accessed on 25 April 2020).

38. IBGE. Planialtimetric Charts. 1971. Available online: ftp://geoftp.ibge.gov.br/cartas_e_mapas/folhas_topograficas/editoradas/ escala_50mil/ (accessed on 25 April 2020).

39. USGS. Earth Explorer. Available online: https:/ / earthexplorer.usgs.gov/ (accessed on 28 August 2016).

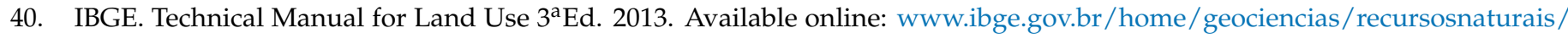
usodaterra (accessed on 24 April 2020).

41. Trevisan, D.P.; Bispo, P.D.C.; Almeida, D.; Imani, M.; Balzter, H.; Moschini, L.E. Environmental vulnerability index: An evaluation of the water and the vegetation quality in a Brazilian Savanna and Seasonal Forest biome. Ecol. Indic. 2020, 112, 106163. [CrossRef]

42. Canter, L.W. Environmental Impact Assessment-Series in Water Resources and Environmental Engineering, 2nd ed.; McGraw-Hill International Editions: Salford, UK, 1996; 660p.

43. Eastman, J.R. Idrisi for Windows, Tutorial Exercises, Version 2.0, Clark Labs for Cartographic Technology and Geographic Analysis; Clark University: Worcester, MA, USA, 1997; 245p.

44. Bojórquez-Tapia, L.A.; Juárez, L.; Cruz-Bello, G. Integrating Fuzzy Logic, Optimization, and GIS for Ecological Impact Assessments. Environ. Manag. 2002, 30, 418-433. [CrossRef] [PubMed]

45. Fritzsons, E.; Mantovani, L.E.; Rizzi, N.E. Riparian Forest Landscapes Indices for Alto Capivari River Basin on Subtropical Carstic Region from Parana, Brazil. Rev. Florest. 2004, 3-11. Available online: https://revistas.ufpr.br/floresta/article/view/2370 (accessed on 10 January 2021).

46. Fushita, A.T.; Reis, R.R.; Faresin, L.; Santos, J.E. Performance of supervised classification in different programs: Comparison through land use and landscape naturalness index. In Annals. XVI Brazilian Symposium on Remote Sensing-SBSR; INPE: Foz do Iguaçu, Brazil, 2013; pp. 6463-6470.

47. Bueno, B.P.S. Índices de urbanização e urbanidade em perspectiva histórica: São Paulo, 1798-1930. Paranoá 1969, 73, 73-82. [CrossRef]

48. Fisher, P.; Wood, J.O. What is a Mountain? Or the Englishman Who Went up a Boolean Geographical Concept but Realized it was Fuzzy. Geography 1998, 83, 247-256. Available online: https:/ / www.jstor.org/stable/40573211 (accessed on 10 January 2021).

49. Marro, A.A.; Souza, A.M.C.; Cavalcante, E.R.S.; Nunes, G.S.B.R. Lógica Fuzzy: Concepts and Applications, Teaching Material. Annals. VII Ibero-American Congress of Educational Informatics; Federal University of Rio Grande do Norte: Lagoa Nova, Brazil, 2013 ; pp. 127-136.

50. Netto, J.N. The Alcohol Saga: Facts and Truths about 100 Years of Fuel Alcohol in Our Country, 1st ed.; Novo Século: Osasco, Brazil, 2007; 343p.

51. Martini, D.Z.; Aragão, L.E.O.E.C.D.; Sanches, I.D.; Galdos, M.V.; Da Silva, C.R.U.; Dalla-Nora, E.L. Land availability for sugarcane derived jet-biofuels in São Paulo-Brazil. Land Use Policy 2018, 70, 256-262. [CrossRef]

52. Rudorff, B.F.T.; De Aguiar, D.A.; Da Silva, W.F.; Sugawara, L.M.; Adami, M.; Moreira, M.A. Studies on the Rapid Expansion of Sugarcane for Ethanol Production in São Paulo State (Brazil) Using Landsat Data. Remote Sens. 2010, 2, 1057-1076. [CrossRef]

53. Moraes, M.C.P.; Toppa, R.H.; Mello, K. Sugarcane Expansion as a pressure factor for protected natural areas. In (Org.) Faces of Landscape Polysemy: Ecology, Planning, and Perception, 1st ed.; Dos Santos, J.E., Zanin, E.M., Eds.; Rima: São Carlos, Brazil, 2013; pp. 163-173.

54. De Mello, K.; Petri, L.; Leite, E.C.; Toppa, R.H. Cenários ambientais para o ordenamento territorial de áreas de preservação permanente no município de Sorocaba, SP. Rev. Árvore 2014, 38, 309-317. [CrossRef]

55. Inkoom, J.N.; Frank, S.; Greve, K.; Walz, U.; Fürst, C. Suitability of different landscape metrics for the assessments of patchy landscapes in West Africa. Ecol. Indic. 2018, 85, 117-127. [CrossRef]

56. Silva, V.C. Current Erosion, Potential Erosion and Sediment Input in the Paracatu River Basin (MG/GO/DF). Ph.D. Thesis, Brasília University, Brasília, Brazil, 2001; 108p.

57. Bertoni, J.; Lombardi, F. Soil Conservation, 6th ed.; Ícone: São Paulo, Brazil, 2008; 355p.

58. Hernandez, R.R.; Hoffacker, M.K.; Murphy-Mariscal, M.L.; Wu, G.C.; Allen, M.F. Solar energy development impacts on land cover change and protected areas. Proc. Natl. Acad. Sci. USA 2015, 112, 13579-13584. [CrossRef] [PubMed]

59. Castro, V.R. Edge Effects on Soil in Cerradão Fragments in the Northeastern Region of São Paulo State, Derived from Agricultural Management. Annals. IX National Cerrado Symposium, Brasília. 2008. Available online: http://simposio.cpac.embrapa.br/ simposio_pc210/trabalhos_pdf/00504_trab2_ap.pdf (accessed on 10 January 2021).

60. Azevedo, T.N. Effect of Expanding Sugarcane Cultivation on the Landscape Composition of São Paulo State, 79f. Master's Thesis, São Paulo University, São Paulo, Brazil, 2013.

61. Macedo, R.C.; Almeida, C.M.; Santos, J.R.; Rudorff, B.F.T. Spatial dynamic modeling of changes in land cover and land use related to sugarcane expansion. Geod. Sci. Bull. 2013, 19, 313-337. Available online: https://sid.inpe.br/mtc-m19/2013/09.06.18.13-TDI (accessed on 10 January 2021).

62. Aspinall, R.; Staiano, M. Ecosystem services as the products of land system dynamics: Lessons from a longitudinal study of coupled human-environment systems. Landsc. Ecol. 2019, 34, 1503-1524. [CrossRef]

63. Zimmermann, C.L. Monoculture and transgenics: Environmental impacts and food insecurity. Law Paths. 2009, 6, 79-100. 
64. Medrano, L.; Recaman, L. Space and society in the 21st century. e case of São Paulo. Bitácora Urbano Territ. 2018, 28, 71-83. [CrossRef]

65. Moschini, L.E. Environmental Zoning of the Upper Mogi-Guaçu Superior River Basin. 149f. Ph.D. Thesis, Universidade Federal de São Carlos, São Paulo, Brazil, 2008.

66. Dos Santos, R.M. The Temporal and Spatial Pattern of Land-Use Changes and Scenarios for the Conservation of Regional Biodiversity in São Félix do Araguaia, MT. 153f. Ph.D. Thesis, Federal University of São Carlos, São Carlos, Brazil, 2011.

67. Fushita, A.T.; Dos Santos, J.E.; De Souza, I.M.M.; Romanini, E.; Costa, R.T. Landscape Structural Indicators as a Tool to Assess Land Use Changes in Planning for Sub-Basin Sustainability (Southeastern Brazil). J. Water Resour. Prot. 2016, 8, 482-492. [CrossRef]

68. Cristache, S.-E.; Vuță, M.; Marin, E.; Cioacă, S.-I.; Vuţă, M. Organic versus Conventional Farming-A Paradigm for the Sustainable Development of the European Countries. Sustainability 2018, 10, 4279. [CrossRef]

69. Szafranska, B.; Busko, M.; Kovalyshyn, O.; Kolodiy, P. Building a Spatial Information System to Support the Development of Agriculture in Poland and Ukraine. Agronomy 2020, 10, 1884. [CrossRef]

70. Tarasovičová, Z.; Saksa, M.; Blažík, T.; Falt'an, V. Changes in Agricultural Land Use in the Context of Ongoing Transformational Processes in Slovakia. Agriculture 2013, 59, 49-64. [CrossRef]

71. Moravcová, J.; Koupilová, M.; Pavlíček, T.; Zemek, F.; Kvítek, T.; Pečenka, J. Analysis of land consolidation projects and their impact on land use change, landscape structure, and agricultural land resource protection: Case studies of Pilsen-South and Pilsen-North (Czech Republic). Landsc. Ecol. Eng. 2017, 13, 1-13. [CrossRef]

72. Bonita, B. Rio Tietê Dam in Barra Bonita. 2019. Available online: http:/ / bes-br.com/?page_id=1507 (accessed on 13 May 2020). 